\author{
УДК 338.14 \\ JEL Q200, Q240, Q300, Q320 \\ ORCID ID: 0000-0003-4989-6322 \\ ORCID ID: 0000-0002-5531-6155 \\ ORCID ID: 0000-0001-5400-9076 \\ ORCID ID: 0000-0003-3267-7123 \\ DOI https://doi.org/10.17721/tppe.2021.42.1
}

Fyliuk H., Doctor of Economics, Professor, Honored Economist of Ukraine

Pimenova O., Ph.D., Associate Professor

Pimenov S., Ph.D., MBA

Golovanenko M., Ph.D., Associate Professor

\title{
RETROSPECTIVE ANALYSIS OF THE IMPACT OF BUSINESS MODELS OF ENTERPRISES ON THE ENVIRONMENT AND SOCIETY
}

The aim of the article is to study the impact of business models of modern enterprises on the environment and society and how this impact has changed in recent decades.

Hypothesis. We assumed that the more economically viable the business model of the enterprise, in the absence of control and regulation, the greater damage cause enterprises to the environment and exacerbate social problems, especially in poor countries.

Research Methodology - The impact of modern business models of large enterprises on socioeconomic environment based on neoclassical approaches of economic theory, as well as the theory of classical school of political economy on the one hand and the concept of sustainable development and the concept of ecological economy on the other hand are analyzed. In addition, the following methods were used in the research process: monographic (analysis of environmental and social consequences of the implementation of existing business models of enterprises); retrospective analysis (analysis of environmental and social consequences in the process of changing business models of enterprises), comparative analysis (identified features of methods of enterprise evaluation, which include the use of integrated method and systematic analysis of information disclosure, as well as CSR activities); empirical (on the assessment of social and environmental consequences of the implementation of business models of large enterprises and the concentration of large tracts of agricultural land in hands of national and transcontinental industrial and commercial companies); abstract-logical (generalization and formulation of main conclusions and proposals based on the results of the study).

Findings - In order to increase the objectivity and completeness of information as to the specifics of companies, in particular, in terms of their impact on the environment, society and other stakeholders, we propose to evaluate companies, primarily on the basis of questionnaires and direct interviews and in secondly is on the basis of information from open sources, as well as to compare them with each other, which should be the subject of further scientific research.

Keywords: business model of the enterprise, sustainable development, rating of enterprises, stakeholders, environmental consequences, social consequences. 
Problem statement. The active development of information technology on the one hand improves the work of enterprises through automation, robotics and digitalization of technologies, increases productivity of enterprises and on the other hand leads to irreversible environmental consequences associated primarily with increased emissions of carbon dioxide into the atmosphere, leads to environmental pollution and climate change and increases social tensions through the dismissal of large numbers of staff and through the digitalization of certain industries (UBER, Airbnb, etc.). Thus, we assumed that the more economically viable the business model of the enterprise, in the absence of control and regulation, the greater damage cause enterprises to the environment and exacerbate social problems, especially in poor countries.

Analysis of publications. The impact of modern business models of large enterprises on socio-economic environment based on neoclassical approaches of economic theory, as well as the theory of classical school of political economy on the one hand and the concept of sustainable development as well as the concept of ecological economy on the other hand are analyzed.

Unresolved parts of the problem. Despite the existing variety of approaches to business model planning, the scientific and applied foundations of forming the viable business model of enterprise require further research, taking into account the the concept of sustainable development as well as the concept of ecological economy.

The purpose of the article is to study the impact of business models on modern enterprises, in particular those that actively implement information technology, on the ecological and social environment.

The aim of the article led to the formulation of following tasks:

1. Investigate the social and environmental consequences of the implementation of business models of modern enterprises.

2. To study the conceptual approaches of sustainable development in order to rationally manage the modern enterprises and increase the efficiency of their business models in conditions of limited and exhaustible resources.

3. To compare modern approaches to the concept of sustainable development with neoclassical approaches of economic theory, as well as approaches to the concept of environmental economics with scientific approaches of the classical school of political economy in order to find patterns of consumption and production that would meet the urgent needs of mankind.

4. Analyze the existing methods of assessing the activities of enterprises as to manage their economic, social and environmental risks, which contribute of improving the efficiency of the business model of the enterprise, in particular: improving the image in local and international markets; increasing trust on the part of stakeholders in its activities (including government agencies); increasing opportunities to attract cheaper investment for long-term development.

Research methodology. The following methods were used in the research process: monographic (analysis of environmental and social consequences of the implementation of existing business models of enterprises); retrospective analysis (analysis of environmental and social consequences in the process of changing business models of 
enterprises), comparative analysis (identified features of methods of enterprise evaluation, which include the use of integrated method and systematic analysis of information disclosure, as well as CSR activities); empirical (on the assessment of social and environmental consequences of the implementation of business models of large enterprises and the concentration of large tracts of agricultural land in hands of national and transcontinental industrial and commercial companies); abstract-logical (generalization and formulation of main conclusions and proposals based on the results of the study).

Results and discussion. Until the early 1970s, business owners and managers in almost no country did not identify their stakeholders in creating business models and did not take their interests into account. Enterprises mostly focused on the growth of production volumes, as there was a shortage of quality goods and services on the market. This, on the one hand, led to a creation of new jobs, increased welfare of the world's leading countries, improved quality of life and on the other hand led to excessive uncontrolled use of limited natural resources, increased material consumption of goods and services and ever-increasing of demand due to the population growth of the Earth.

In the mid-70s of the twentieth century there was a significant increase in production, the negative aspect of which was the exacerbation of environmental problems worldwide. This raised the question of world leaders and activists about the environmental situation in the separate countries and in the world as a whole. Thus, in 1972, the authors of the report "Limits of Growth" of the Club of Rome on the project "Problems of Humanity" based on modeling the dynamics of population growth and gradual depletion of natural resources predicted 12 scenarios of civilization, among which negative, in particular, basic (Meadows, D., Randers, J., Behrens, W., 1972 [1]). In 2008, G. Turner (Australia) published an article comparing the forecasts of "Growth Limits" with actual data for the last 30 years (Turner, G., 2008 [2]). The author concludes that the results of production of goods and products, environmental pollution correspond to the values calculated in the model of the baseline scenario of 1972. In 2016, the world's population exceeded 7.3 billion people, and is projected to increase by 2050 up to 9.7 billion (UN on women's rights: full gender equality is still a long way off, 2015 [3]). Since 1990, the world's arable lands have hardly increased, and the use of new, less suitable plants can lead to a significant increase in agricultural production and negative consequences for the environment, it means an increase in the number of deserts, as is the case in Africa (Kovalev, E., 2004 [4]).

In the 70 s of the twentieth century increased concerns among the progressive community about the scarcity of natural resources and climate changes have led to the emergence of non-governmental scientific organizations to study the global human problems, such as the International Federation of Advanced Research Institutes, the Club of Rome, the International Institute for Systems Analysis. In 1972, the UN Conference was held in Stockholm, which launched the United Nations Environment Program (UNEP). Thus, this was the beginning of the involvement of the international community in solving the environmental problems, which led to the emergence of the first ministries and agencies for environmental protection in different countries. 
In the 1980s, the question of the development of civilization in relation to environmental management, the question of ecological development and the need for sustainable development of the eco-system became relevant. In 1980, the World Conservation Strategy (WSP) for the first time in an international document enshrined the concept of "sustainable development". The second edition of the WSP, adopted 11 years later, is entitled "Caring for Planet Earth - Strategies for Sustainable Living", which emphasizes the need to preserve nature, protect biodiversity, landscapes and ecosystems, the rational use of natural resources and renewable resources.

In 1987, in the report "Our Common Future", the International Commission of Environment and Development (ICED) paid considerable attention to the need for sustainable development, in which the needs of the present generation do not limit future generations to meet their needs. This formulation of the concept of sustainable development at the present stage is widely used in many countries around the world.

Since the end of the XX century, the development of science and technology has contributed to the improvement of business models of enterprises, which is primarily due to the widespread use of IT tools. In particular, the creation of data centers, the need to process huge amounts of information, which doubles every 1.5-2 years, the introduction of new energy-intensive technologies such as bitcoin and others require more electricity, which negatively affects both on the environment and exacerbates social problems. Since the beginning of 2020, the problem has only deepened, as the global quarantine caused by the COVID 19 pandemic has led to the transition to online remote work, learning, communication using distance learning technologies and ways of organizing work (Zoom, Skype, Meet, etc.) on the one hand and exacerbated the problem of plastic disposable waste on the other hand. This conclusion is confirmed by expert Alex Weissner-Gross, who believes that the amount of carbon dioxide emissions into the atmosphere when viewing the web page is about 0.02 grams of carbon dioxide per second. This figure increases 10 times (up to 0.2 grams per second) when viewing a website with complex images, animations or video images. And that's trillions of views every day around the world.

Sustainable development means stopping the irrational use of non-renewable and depleting natural resources and activities that will take into account the interests of future generations. At the same time, in the face of growing competition, the pursuit of profit maximization to achieve such a goal in the short term is impossible. Sustainable development of countries and enterprises requires special attention and control by the community and activists in order to prevent further destruction of natural resources for the sake of rapid enrichment.

Artificial intelligence technologies are an important tool that can help to achieve sustainable development goals and prevent catastrophic global change. The nature of their impact is assessed by researchers in different ways, but more convincing is the view that in general, artificial intelligence contributes to most of the goals of sustainable development. Thus, according to (Vinuesa, R., Azizpour, H., Leite, I. et al. [26]) artificial intelligence technologies will contribute to the achievement of 134 targets defined in the 
"2030 Agenda for Sustainable Development". However, researchers acknowledge that artificial intelligence will also create risks to achieve 59 targets.

The World Bank's conceptual approaches to sustainable development involve sound management of the country's asset portfolio, which means preserving and enhancing the capacity of communities where assets are not only traditional physical but also include natural and human capital. Sustainable development, first of all, involves the growth (or at least not reduction) of existing assets in the future, the rationality of the behavior of all economic entities managing the country's economy.

In a broad sense, the sustainable development combines a threefold concept: the unity of economic, social and environmental approaches. The economic approach to the concept of sustainable development is based on the theory of maximizing the total income of J. R. Hicks and E. Lindal, which can be obtained by maintaining the total capital that forms this income. This concept provides for the optimal and rational use of limited resources and the use of energy and resource-saving technologies, as well as waste minimization and reuse.

The social approach to sustainable development is human-centered and preserves the stability of social and cultural systems, including the reduction of local, regional and international conflicts. An important element of this approach is the fair distribution of benefits and equal opportunities for all. Given the value of freedom, which provides a variety of choices, the concept of sustainable development implies that a person must participate in the processes that shape the sphere of his/her life, facilitate the adoption and implementation of decisions and monitor their implementation.

The ecological approach to sustainable development foresees the integrity of biological and physical natural systems, including the viability of local ecosystems, on which the global stability of the entire biosphere depends. Under the elements of ecosystems should be understood not only nature but also systems created by mankind, in particular small and large cities, large enterprises. As for enterprises, the concept of sustainable development implies the preservation of the ability to self-recovery and dynamic adaptation to progressive change. The negative impacts of enterprises on the environment include: degradation and depletion of natural resources, environmental pollution, significant greenhouse gas emissions, loss of biodiversity etc., which reduces the ability of ecosystems to self-healing.

Reconciling the above approaches to achieve sustainable development is the most difficult task and challenge for modern society, as all three approaches must be considered simultaneously and in a balanced way. The interconnectedness and interaction of economic and social elements give rise to new challenges, which means achieving an equity in the distribution of income and benefits and ensuring a decent standard of living for the poor. Consideration of environmental and economic aspects by enterprises has led to the emergence of a new type of reporting (is mandatory in developed countries) as to the impact of enterprises on the environment. Finally, the relationship between environmental and social aspects raises issues such as intergenerational justice, respect for the rights of future generations and the participation of citizens in key decision-making. 
As we can see, the concept of sustainable development does not correspond to the classical approaches of neoclassical economic theory, which assumes continuous economic growth. Therefore, economists and scientists suggest finding a scheme of consumption and production that would meet the urgent needs of mankind. Traditional economic approaches for doing business are aimed at maximizing profits, which is equated with maximizing public welfare. At the same time, within the framework of this area of economic theory, there is an opinion that the shortcomings of a market economy can be corrected by public policy and social programs. In contrast, according to the concept of sustainable development, maximizing profits and meeting the growing needs of individual consumers inevitably leads to depletion of natural and social resources, which are the basis of human well-being and ensure their livelihoods.

According to the concept of ecological economy, theoretical approaches to the problem of ensuring economic growth taking into account the social and environmental consequences are formulated. Proponents of this approach in 2004 created a center of the development of a stable economy. In the works of $\mathrm{H}$. Daly is introduced the concept of "sustainable economy", some components of which are stable and do not change over time. Canadian economist P. Victor proposed an interactive model that explores the potential for a stable, non-growing economy (Victor, P., 2008 [5]). The model demonstrates that even within the framework of generally accepted approaches in the economy there is an opportunity to achieve a stable state.

Extending the context, we note that the idea of a sustainable economy is not new. A. Smith in his work "Study of the nature and causes of wealth of peoples" noted that based on selfishness and self-interest of market participants with a sufficient level of economic freedom can get goods in the required quantities, increase wages, increase production and consumption (Smith, A., 2016 [6]). However, the scientist saw the other side of this process. According to him, population growth in the future will lead to lower wages, natural resources will be depleted and the division of labor will reach its limits of efficiency. At the end of the XVIII century A. Smith estimated the maximum period of population growth in 200 years. At the present stage, the issue of population growth and improving the efficiency of enterprises, taking into account their impact on the environment has become particularly relevant.

J. St. Mill in his Principles of Political Economy noted that the growth of wealth is not an endless process, as it can lead to a constant state. At the same time, the immutability of capital and population does not imply the immutability of human perfection. When benefits cease not to be a priority, more time and opportunity for spiritual culture, moral and social progress appears (Mill, J., 1848 [7]).

Thus, thinkers, scientists and well-known economists at different times emphasized the need to maintain and increase welfare. So, the concept of sustainable development is becoming especially relevant today. Increasing competition and excessive consumption of natural resources, the pursuit of large enterprises to maximize profits leads to problems caused by significant climate change and global warming.

Earth's climate change is considered as a statistical deviation of weather parameters from long-term values for certain, fairly long periods of time. This takes into account 
changes in both the average values of weather parameters and changes in the frequency of extreme natural phenomena (earthquakes, hurricanes, floods etc.). Such changes are caused by dynamic processes on Earth (as in one of the space objects), changes in the level of solar radiation and excessive human activity over the past two centuries, including the activities of large and very large industrial enterprises.

Today, the main problems associated with the activities of enterprises that have a negative impact on the environment include:

- constantly increasing concentration of $\mathrm{CO} 2$ in the atmosphere (due to combustion of different types of fuel);

- increase in the atmosphere of various aerosols that affect its cooling;

- irrational land use on an industrial scale (in particular, the activities of agricultural holdings and large agricultural enterprises) (Pimenova O., Pimenov S., 2017 [8]);

- deforestation, etc.

Uncontrolled activities of large enterprises have an anthropogenic impact on the environment and cause the global warming, which has been observed on the planet for over 100 years. Beginning from 1850, each subsequent decade was warmer than the previous one. Over the past two centuries, due to the activities of enterprises, the planet's temperature has increased by 0.8-1.2 degrees Celsius. According to different climate change scenarios, in the case of maximum greenhouse gas emissions, the projected increase in temperature will be 2.6-4.8 degrees in XXI century (Stoker, T., Qin, D., 2013 [9]). As climate change is inert, even under the hypothetical scenario of a complete cessation of negative effects of industry and agriculture on a climate, the average temperature will rise by at least 0.6 degrees Celsius.

As stated on the official website of the UN, exceeding the thresholds that have already occurred, lead to irreversible changes in ecosystems of our planet (Global Agenda: Climate Change., 2020 [11]). In October 2018, the Intergovernmental Panel on Climate Change (IPCC) published a special report on global warming at 1.5 degrees. The report highlights a number of avoidable climate change consequences. The report concludes that limiting warming to 1.5 degrees requires immediate transitions in land, energy, industrial systems, as well as transport and large cities. Carbon dioxide emissions caused by human activities need to be reduced by almost half by 2030, compared to 2010 levels.

In September 2019, an UN-sponsored climate meeting was held, at which world leaders presented reports on measures taken by their countries ahead of the Conference on Climate Change to be held in late 2020. The summit focused on key issues on climate change, namely, the impact of heavy industry on climate change, the activity of large cities, in particular in energy issues and the financing of measures to fight against climate change. The 2020 Conference (which was postponed to 2021 due to the coronavirus pandemic) planned to clarify and expand countries 'commitments on global warming.

Global warming has extremely important consequences for the planet and humanity, in particular:

- rising ocean levels;

- change in the amount and nature of precipitation;

- increase in deserts volume; 
- increase in the frequency and scale of extreme weather events (hell waves, droughts, downpours);

- oxidation and pollution of the ocean;

- extinction of biological species due to changes in temperature;

- threat to food security due to changes in yield and quantity of arable land;

- climatic migration of population from traditional places of residence.

Under such conditions, the sustainable development of territories and humanity is unlikely. At the same time, the activities of only certain international and national institutions, related to the control and regulation of activities of all other economic entities at national level and on a global scale, do not provide a substantial positive result. The biggest role in preserving the environment belongs to its main polluters, there are enterprises. According to Fr. Lalu, an expert in the field of organizations, a consultant on effective business modeling, "The modern way of doing business has outgrown our planet. Our companies make a huge contribution to the depletion of natural resources, the destruction of ecosystems, climate change, the depletion of water and precious arable land. We play with the future, balancing on what is allowed, betting that technology will heal the wounds are being caused to the planet by progress. An economic model built on growing profit with limited resources will inevitably come to a standstill... It will not be an exaggeration, but a sad reality, that the very survival of many species, ecosystems, and perhaps humanity, depends on our ability to move to more advanced forms of consciousness and work together according to new methods that can eliminate our losses" (Lalu, F., 2019 [12]).

Environmental problems, climate change and global loss are extremely relevant for Ukraine as well. Although today such disasters passes our country (as devastating hurricanes and tornadoes, large-scale forest fires, pollution of the world's oceans, in particular, the winter of 2019-2020 without snow and with an average temperature exceeding several degrees of historical highs, as we can see that global loss with its negative consequences, it is only a matter of time.

In Ukraine, one of the main polluters of the environment is agriculture and energy sector, whose activities are formed primarily by the ever-growing demand of the information technology industry. Emissions of pollutants and greenhouse gas emissions of fuel and energy complex is about $40 \%$ of emissions of all sectors of the economy and $58 \%$ is from stationary sources of pollution. To some extent, this also affects the temperature in our country. Over the past 30 years, the average annual temperature in Ukraine has risen by $1^{\circ} \mathrm{C}$. The period from the end of the twentieth century and to present time is the warmest in the history of weather observations in Ukraine (since the 1890s). The rate of change of average, as well as maximum and minimum temperatures for the period 1961-2013 was $0.3^{\circ} \mathrm{C}$ every ten years (Climate change in Ukraine and the world: causes, consequences and solutions to counteract., 2020 [10]). As a result, droughts intensified, the water content of rivers and lakes changed and extreme weather events uncharacteristic of Ukraine appeared. All of them have a negative impact on the enterprises of the agro-industrial complex and therefore they will be forced to adjust their business models and increase the costs of counteracting and eliminating losses. 
Due to the anthropogenic load in our country, about $70 \%$ of surface waters and a significant share of groundwater reserves in Ukraine have lost their importance as a source of drinking water. In recent years, the water level in the rivers of Ukraine in summer is below normal. Therefore, with more frequent droughts and reduced rainfall in the summer, the situation can only get worse. Although the average annual rainfall has changed insignificantly, there are changes in the intensity and nature of their precipitation: for example, half or a monthly precipitation rate may fall in a few hours. According to scientists, in Dnieper for the period 2030-2040 will be less water by 29\% and in Dniester will be less by $37 \%$ (Report on research work on spatial analysis of changes in water regime of basins of surface water bodies on the territory of Ukraine due to climate change, 2013 [13]). This will reduce yields and problems with nuclear power plants. Nuclear power, which supplies more than $50 \%$ of electricity, requires constant cooling, but due to the reduction of river water, there is a high risk of overheating of reactors.

The negative impact on the quality of land has activities of agricultural holdings that use tens of thousands of hectares of farmland for growing the most profitable and technologically mechanized crops (sunflower, canola, spiked cereals, maize) with chemical fertilizers, pesticides, herbicides and other crop protection products to increase yields (Pimenova, O., Pimenov, S., 2016 [14]). In general, agricultural holdings today concentrate about 5 million hectares of land. It should also be emphasized that the business model of agricultural holdings in Ukraine is aimed solely at making a profit and increasing the capital of their founders. Maintenance and development of rural infrastructure was not considered by the owners of agricultural holdings as part of their business models, because the founders or owners of agriholdings, as a rule, do not live at places of agribusiness and they do not need to use rural infrastructure (Fylyuk, $\mathrm{H}$., Pimenov, S., 2019 [15]). Existing land use practices worsen the condition of land and the depleting use of land, forest and water resources leads to irreversible loss of biodiversity.

The issues of waste management and provision of centralized water supply to rural population remain problematic. Every year about 4 million tons of pollutants are released into the air basin. Unfortunately, it should be noted that only due to the economic downturn in Ukraine have significantly reduced greenhouse gas emissions, emissions and discharges of pollutants into the environment, reduced waste generation (Sustainable Development Goals: Ukraine. National Report, 2017 [16]).

To address global issues, the UN Framework Convention on Climate Change was adopted in 1992, ratified and acceded to by almost all countries (197 countries). Its main goal is to prevent the threatening anthropogenic impact on the planet's climate. Adopted in 1997, the Kyoto Protocol, to which 192 countries are parties, obliges developed countries to reduce greenhouse gas emissions. The first commitment period was set from 2008 to 2012, and the second from 2013 to 2020.

In 2016, the leaders of 175 countries (including Ukraine) signed the Paris Agreement in New York, which was ratified by the Verkhovna Rada of Ukraine on July 14, 2016. Its main goal is to implement measures that should lead to the restraint of environmental temperature rises within $20 \mathrm{C}$ by the end of this century, and to try to keep the rise within $1.50 \mathrm{C}$. It is planned to monitor the implementation of the agreement every 5 years, the 
next of which scheduled for 2023. However, this agreement is also considered imperfect by the expert community. Thus, according to climate change expert J. Hansen, it is only declarative, as it consists only of goals and intentions (Milman, O., 2015 [17]). This is confirmed by the fact that $\mathrm{CO} 2$ emissions in Ukraine are one of the most delicate in the world. As of August 2019, it has a population of $10 \mathrm{UAH} / 1$ ton (about $\$ 0.36$ ), which is 386 times lower than in Sweden. The High-Level Commission on CO2 Emissions concluded that "the $\mathrm{CO} 2$ emission price, which is responsible for achieving the price category of the Paris Agreement, should create at least 40-80 US dollars / 1 ton, with a prospect of 50-100 US dollars / $1 \mathrm{t}$ by 2030 to reach the level of the Paris Agreement and prevent an increase in global temperature at $+1.5^{\circ} \mathrm{C}$.

The next important aspect of the sustainable development economy is the social component. Many modern scientists and practitioners point out the need to change approaches to modern business modeling, in particular, in terms of taking into account the social component. Thus, H. Gemel emphasizes: "Subconsciously we feel that our management is outdated" (Lalu, F., 2019 [12]).

It is assumed that in modern society the main reference point, the driving goal of production in enterprises should be people. Therefore, one of the most important elements of the component of sustainable development, in our opinion, is the fair distribution of income and benefits, both between individual employees within the enterprise and within a particular region, country and the world. The concept of sustainable development stipulates that a person should have equal opportunities with other people and participate in decisions related to the sphere of his life and promote their implementation, including through the ability to monitor and control their implementation.

In public international law, the document enshrining human rights is the UN Universal Declaration of Human Rights. The document was adopted on December 10, 1948 at the UN General Assembly. The text consists of 30 articles and is a global determinant of the rights enjoyed by everyone on planet Earth (Universal Declaration of Human Rights, 1948 [18]). Among human rights are: personal (rights to life, punishment through the court, personal integrity etc.), political (equality before the law, freedom of speech and press, freedom of assembly etc.), socio-economic (right to work, education, housing etc.). Respect for human rights contributes to better motivation of employees in the workplace and, consequently, to more efficient work.

In Ukraine, the following factors can be identified that negatively affect the human potential of the country: danger to human life and health, violence, including against women, inequality and discrimination, increasing extreme poverty, increasing the number of socially vulnerable groups. The impact of unresolved social problems in Ukraine on living standards has been exacerbated by the effects of the armed conflict in the east. Restoring economic growth and ensuring equal access for all women and men to participate in economic, social and political life, as well as to basic social services (especially in education and health) are urgent challenges to sustainable development.

In terms of gender equality, in particular the observance of women's rights, providing them with equal opportunities with men, in 2019 Ukraine ranked 52nd out of 189 on the Gender Inequality Index from the UN Development Program. In Ukraine today, there is a 
trend of lower wages of women compared to men, women hold lower positions (the percentage of women among top managers of enterprises and supervisory boards is low). For example, in Sweden and France, women earn 31\% less than men, in Germany earn $49 \%$ less and in Turkey the pay gap is $75 \%$ (UN on women's rights: full gender equality is still a long way off, 2015). Ensuring the gender equality is a challenge for Ukraine. Achieving gender parity in public administration and in the management of commercial structures remains an urgent task, despite the achievements and changes at the legislative and institutional levels. The gap in the average wage between men and women (about $30 \%$ ) is another manifestation of gender inequality (Sustainable Development Goals: Ukraine. National Report, 2017 [19]).

Ukraine, represented by the Ministry of Economic Development and Trade (now the Ministry of Economic Development, Trade and Agriculture of Ukraine), in its report "Sustainable Development Goals: Ukraine" provides its vision of Sustainable Development Goals (SDGs) approved at the UN Summit. Taking into account the principle of "no one to leave aside" and using huge arrays of information, statistical and analytical materials, a national system of SDG was developed (86 tasks of national development and 172 indicators for their monitoring), aimed at further planning of Ukraine's development and monitoring Sustainable Development Goals: Ukraine, National Report, 2017). Thus, both at the global level and at the level of individual enterprises, work continues to address problems that lie in the plane or have implications for the social, environmental and economic sectors around the world in a broad sense.

An important issue in the implementation of the concept of sustainable development, given its evolutionary nature, is the development of practical indicators. Both international organizations and scientific institutes are currently working on this issue. Whole standards of indicators for individual territories and continents are emerging. Such indicators simultaneously measure environmental, economic and social aspects for the same enterprise or territory. An example of the practical application of systems of indicators is the indices of sustainable development, which combine all three components. Such indicators are multifactor growth indices, which are taken into account by potential investors on individual stock exchanges when estimating the value of enterprises whose shares are listed on these exchanges.

One of the most comprehensive indicators systems is the United Nations Sustainable Development Goals System, developed and approved in 2017 by the United Nations Commission on Sustainable Development (SDG Indicators. Global indicator framework for Sustainable Development Goals and targets of 2030 Agenda for Sustainable Development [20]). The indicators are divided into the following main groups:

- social indicators of sustainable development;

- economic indicators of sustainable development;

- environmental indicators of sustainable development (including characteristics of water, land, air, other natural resources and waste);

- institutional indicators of sustainable development (policy, research, international legal instruments, information support, strengthening the role of major groups). 
The proposed indicators are designed for the period up to 2030. Achieving the planned value of these indicators requires individual countries to implement specific reforms. The indicators are divided into 3 categories taking into account their target orientation:

- indicators as a driving force that characterize the activities of mankind and the processes that affect sustainable development;

- status indicators that characterize the current state of various aspects of sustainable development;

- response indicators that allow you to respond in a timely manner for changing current trends. This can be a political, technological or other way of responding.

Thus, with the aim of leveling the social and in particular environmental impact on the environment in modern economic conditions and the rapid development of information technology, in our opinion, it should be the preparation of social, in particular integrated reporting.

The standard of social reporting is a set of rules, documents, indicators that create certain requirements for the reports of enterprises for the results of their activities within the corporate social reporting. Such standards are used by various international multinational companies as benchmarks for preparing financial statements. A non-financial report is a public document of an enterprise that listens to inform stakeholders about its activities and impact on the environment, community, social issues and so on. The structure of the social report, in addition to the results of activities, contains plans and responsibilities that the company assumes for social and environmental initiatives.

Today there are different standards of social reporting, among the most common are GRI, ISO26000 and AA1000AS. Using the standard allows you to compare the activities of different companies. The social report, which the company issues on a regular basis, disciplines the company for its own plans and initiatives in the field of sustainable development to its stakeholder groups.

Reporting in the context of the sustainable development of the Global Reporting Initiative (GRI) is an international standard that offers a specific list of indicators for reporting on the environmental, social and economic performance of enterprises. The standard was established in 1997, with the support of the United Nations. A draft version of the standards was released in 1999 (Global Reporting Initiative (GRI) presents Exposure Draft of the Sustainability Reporting Guidelines, 1999 [21]). Among the advantages of this standard is the possibility of a gradual transition to social reporting, as the company in the early stages can use the general principles of reporting, later can disclose activities in a particular area of important issues, and finally choose those areas of issues and indicators as to the own activity on a regular (for example - annual) basis.

The ISO 26000 social reporting guide was issued by the International Organization for Standardization in 2010. About 400 experts representing the interests of consumers, the state, workers and the professional community participated in the development of the standard. The standard describes how businesses can be socially responsible, i.e., contribute to the health and well-being of society. At present, this standard is not envisaged for the certification and audit of enterprises. The standard provides an approach to conducting socially responsible business and provides an opportunity to integrate socially 
responsible behavior into the strategy, practice and business processes of the organization. To implement the ISO 26000 standard, the organization must independently, through dialogue with stakeholders, identify important issues that it must respond to and develop.

The AA1000 AS corporate social reporting standard was developed by the British Institute for Social and Ethical Reporting in 1999. The standard is designed to measure the performance of companies in ethical terms, provides a procedure and a set of criteria by which their activities can be audited. The main feature of this standard is the introduction of dialogue with stakeholders and on its basis is the adjustment of the system of indicators.

In international practice there are various social reporting standards that companies use when preparing non-financial reports. Among the key benefits that the company receives by issuing a non-financial report should be noted:

- improving the image in local and international markets;

- growth of trust on the part of stakeholders in its activities (including government agencies);

- increase opportunities to attract cheaper investments for long-term development.

In the international practice of doing business for more than 10 years companies form integrated reporting in order to disclose the results of their own work for a wide range of stakeholders and increase the efficiency of their own business models.

Integrated reporting is a reporting that is disclosed by enterprises in four main dimensions: economic, social, environmental and governance. In other words, such reporting is based not only on financial indicators but also on non-financial ones, in particular, it includes: business model and strategy of enterprise development, ecological and social component of enterprise activity, enterprise management methods, company development plans, enterprise results etc. Integrated reporting should provide stakeholders with information on the long-term development of the enterprise, in contrast to financial statements, which cannot fully provide such information and actually record the results of previous periods. That is, the main purpose of integrated reporting is to explain to investors, creditors and other stakeholders how the company creates and plans to produce value in the future over a long period of time.

In international practice, integrated reports began to take shape in the mid-2000s. A new nomination "Best Integrated Reporting" has appeared at the International Competition as to annual reporting the Corporate Register. Later, the Prince of Wales initiated the Accounting for Sustainability Accounting to form the document the Connected Reporting Framework. Subsequently, in 2009 the organization issued another document Connected Reporting, and in 2010 these developments were transferred to the established International Council on Integrated Reporting.

Thus, in 2010, the International Integrated Reporting Council (IIRC) was established. It was initiated by the International Federation of Accountants (IFAC), the Global Reporting Initiative (GRI), participants of project of the Sustainability Report (A4S), the International Organization for Standardization (ISO) and others. The main task of the IIRC was to develop the Concept of Integrated Reporting and prepare a draft of International Standard 
on Integrated Reporting. In 2013, after numerous consultations and tests by individual companies and investors in different regions of the world, including 140 companies and investors who participated in the IIRC pilot program, an integrated reporting structure was formed.

This approach assumes that this structure was developed by the business in response to a new, broader value model that:

- provides benefits for stakeholders, in particular investors, as international reporting should provide investors with complete information on the development of the enterprise;

- strengthens the leading role of the financial director at the enterprise. That is why CFOs are best placed to stimulate integrated reporting as a means of providing information on how their businesses create value over time;

- combines integrated thinking and reporting. Reporting and thinking must complement each other. They are needed in enterprises to strengthen the connection and communication of enterprise management with stakeholders on value creation;

- emphasizes the importance of human capital in the enterprise.

Among the best-known ratings of companies used in international practice to assess the compliance of enterprises with social standards is the Dow Jones Sustainability Indices (DJSI), which was introduced in 1999 and represents a family of indices with the ability to assess a large number of companies around the world as to the sustainable development. Today, the index includes more than 3,000 multinational companies from all continents. The index has become a key reference point for investors in companies that adequately manage non-financial risks. DJSI is based on the analysis of corporate, economic, environmental and social indicators and evaluates such issues as corporate governance, risk management, branding, climate change mitigation, supply chain standards, labor relations etc. The ranking includes general and sectoral criteria for sustainable development for each of the 61 industries. DJSI includes the main global index DJSI World, indices based on various regions (Europe, North America, Asia-Pacific, North Europe, Korea) and industry indices. To be included in DJSI families, companies are selected on the basis of their long-term management plans for economic, social and environmental issues. The selection criteria change annually, and in order the company not to be excluded from the rating, it must constantly improve long-term sustainable development plans. The indices are updated annually, but enterprises are monitored throughout the year.

Another FTSE4Good Index was introduced in 2001 by the FTSE Group and is a series of ethical investment stock market indices and launched the Socially Responsible Investment (SRI). These indices take into account stock quotes from companies in the UK, US, European Union and Japan, including a number of criteria based on environmental sustainability, relationships with stakeholders, human rights, labor standards, supply chain and anti-corruption. The index excludes companies identified in the manufacture of tobacco or tobacco products, trade or production of weapons, nuclear weapons etc. 
Corporate Knights Global 100 Most Sustainable Corporations in the World (hereinafter referred to as Global 100) is a European index and primarily notes international companies that most effectively manage environmental, social and managerial risks and opportunities. Among the evaluation parameters: energy efficiency, $\mathrm{CO} 2$ emissions, the ratio of the salary of the head of the company and the average salary of the employee, staff turnover, the dependence of the remuneration of top managers on the achievement of sustainable development goals. When compiling the Global 100, 12 key performance indicators are taken into account (Kyryliuk, N., 2015 [22]).

Conclusion. As we can see, a cost-effective business model of an enterprise is not always effective, because an effective business model involves the management of not only economic but also environmental, social and corporate risks. Therefore, one of the ways to eliminate the negative social and environmental consequences of business models of modern enterprises on the environment, in particular in the context of rapid development and use of information technology, in our opinion, should be the practice of integrated reporting in Ukraine. Integrated reporting should contain the following main components: business model of the enterprise, external environment, opportunities and risks, strategy of enterprise development, results of activity, management, plans for development of the company. Among the main objectives of integrated reporting are:

- providing complete information to stakeholders on the long-term development of the enterprise;

- reflection of the relationship between environmental, social, managerial and economic indicators of the enterprise;

- providing an assessment of the enterprise in the long run;

- providing the most complete and objective information about the activities of the enterprise.

In order to form an effective business model and create additional values in the long run, we believe that in Ukrainian enterprises CEOs and CFOs need to start the practice of collecting and disseminating among investors and other stakeholders all information in the form of integrated reporting on value creation, the results its activities, probable opportunities and risks, as well as prospects for development. By providing information on value creation, including competitive advantage, strategic assets, environmental, social and managerial indicators (ESG), the company will gain an advantage over competitors by effectively implementing its business model and will be able to achieve sustainable development in the long run.

Another direction as to reduce the negative impact of enterprises on the environment in the implementation of their business models is to stimulate the participation of enterprises in ratings to manage their economic, social and environmental risks, which contribute to improve the business model of the enterprise, in particular: improving image at local and international markets; increasing trust on the part of stakeholders in its activities (including government agencies); increasing opportunities to attract cheaper investment for longterm development.

In Ukraine at different times there were separate ratings of companies to assess the performance of enterprises in managing their economic, social and environmental aspects. 
Among them is the Center for the Development of Corporate Social Responsibility (hereinafter the Center for CSR Development). Since 2011, the CSR Development Center has been compiling the Transparency Index for Ukrainian companies' websites based on its own methodology developed in cooperation with Beyond Business (Israel) (Transparency Index of Ukrainian Companies, 2019 [23]). The information base of the rating is the websites of companies. According to the companies' websites, the level of corporate social responsibility (CSR) disclosure is assessed according to four criteria: reporting, content, navigation and accessibility. The weight of the criterion "Content" is $55 \%$, the criterion "Reporting" is $20 \%$, "Navigation" is $8 \%$ and "Accessibility" is $17 \%$. The company's position in the Index relative to other companies is the sum of points (expressed as a percentage) received by each company according to the listed criteria.

In addition, in Ukraine there is a practice of holding local, in particular one-time competitions for the selection of projects and programs in the field of corporate social responsibility, which are conducted by certain publishers and the media. To participate in such ratings, the participating company must submit information about charity, environmental projects etc. to the organizing committee. As a result, a certain evaluation of such projects is carried out for compliance with the competition criteria, and the leaders consist of the so-called "TOP-10", "TOP-20", "TOP-25" companies, etc. Such examples are the TOP-25 companies from the magazine "Power of Money" (Lavnikevich, D., 2020 [25]), "TOP-20" from the publishing group "Cartel" (UNIAN. The top 20 companies that implement the best corporate and social practices in Ukraine were noted in Kyiv [27]). Undoubtedly, on the one hand, this practice is positive for the country and for the companies themselves, as it increases the interest in socially responsible business. At the same time, participation in such ratings and competitions for participating companies primarily increases their image, rather than the quality and efficiency of their business models.

In order to increase the objectivity and completeness of information as to the specifics of companies, in particular, in terms of their impact on the environment, society and other stakeholders, we propose to evaluate companies, primarily on the basis of questionnaires and direct interviews and in secondly is on the basis of information from open sources, as well as to compare them with each other, which should be the subject of further scientific research.

\section{References}

1. Meadows, D., Randers, J., Meadows, D., Behrens, W. (1972) The Limits to Growth: A Report for the Club of Rome's Project on the Predicament of Mankind. Universe Books. $211 \mathrm{p}$.

2. Turner, G. (2008). A Comparison of «The Limits to Growth» with Thirty Years of Reality. Commonwealth Scientific and Industrial Research Organisation (CSIRO). doi:10.1016/j.gloenvcha.2008.05.001

3. UN on women's rights: full gender equality is still a long way off. (2015) URL: https://news.un.org/en/story/2015/07/1267871\#.Vbtw9_ntlBc

4. Kovalev, E. (2004). The global food problem. World economy and international relations. № 10. P. 26-34.

5. Victor, P. (2008). Managing without Growth - Slower by Design, not Disaster. Edward Elgar Publishing. 272 p.

6. Smith, A. (2016) A study of the nature and causes of the wealth of peoples. M .: Exmo. $887 \mathrm{p}$.

7. Mill, J. (1848). Principles of Political Economy with some of their Applications to Social Philosophy. URL: https://www.econlib.org/library/Mill/mIP.html?chapter_num=1\#book-reader 
8. Pimenova O., Pimenov S. (2017). Impact of integration processes in formation business-models of agriindustrial enterprise. Zarządzanie finansami i rachunkowść. Journal of financial management and accounting Szkoły Głównej Gospodarstwa Wiejskiego w Warszawie. № 5 (4). P. 61-73.

9. Stocker, T., Qin, D. (2013). Climate change 2013. Physical science basis. URL: https://www.ipcc.ch/site/assets/uploads/2018/03/WG1AR5_SummaryVolume_FINAL_RUSSIAN.pdf

10. Climate change in Ukraine and the world: causes, consequences and solutions to counter. (2020). URL: https://ecoaction.org.ua/zmina-klimatu-ua-ta-svit.html

11. Global Agenda: Climate change. (2020). URL: https://www.un.org/en/sections/issues-depth/climatechange/index.html

12. Lalu, F. (2019). Companies of the future. Second edition. Kharkiv: Family Leisure Club. 2019. 543p.

13. Report on research work of spatial analysis of changes in water regime of basins of surface water bodies on the territory of Ukraine due to climate change. (2013). URL: https://uhmi.org.ua/project/rvndr/avr.pdf

14. Pimenova, O., Pimenov, S. (2016). Analysis of development and formation of business models of agroindustrial enterprise in the conditions of European integration. Collection of scientific works "Theoretical and applied issues of economics". № 2 (33). P. 146-157.

15. Fylyuk, H., Pimenov, S. (2019). Prospects of changing the efficiency of the business model of Ukrainian agriholdings in the implementation of land reform in Ukraine. Finance $w$ dzialalnosci gospodarczei - teoria I praktyka. Monograph. Part I. Warszawa. 2019. P.25-32.

16. Цілі сталого розвитку: Україна. Національна доповідь 2017. URL: http://un.org.ua/images/SDGs_NationalReportUA_Web_1.pdf

17. Milman, O. (2015). James Hansen, father of climate change awareness, calls Paris talks 'a fraud'. The Guardian (London). URL: https://www.theguardian.com/environment/2015/dec/12/james-hansen-climatechange-paris-talks-fraud

18. Universal Declaration of Human Rights. (1948). URL: https://www.un.org/en/documents/decl_conv/declarations/declhr.shtml

19. Sustainable Development Goals: Ukraine. National Report 2017. URL: http://un.org.ua/images/SDGs_NationalReportUA_Web_1.pdf

20. SDG Indicators. Global indicator framework for the Sustainable Development Goals and targets of the 2030 Agenda for Sustainable Development. URL: https://unstats.un.org/sdgs/indicators/indicators-list/

21. Global Reporting Initiative (GRI) presents Exposure Draft of the Sustainability Reporting Guidelines. (1999). URL: https://www.sustainability-reports.com/global-reporting-initiative-gri-presents-exposuredraft-of-the-sustainability-reporting-guidelines/

22. Kyryliuk, N. (2015). Corporate social responsibility: the experience of European companies. A young scientist. № 2 (17). P. 107-110.

23. Transparency Index of Ukrainian Companies (2019). URL: https://csr-ukraine.org/wpcontent/uploads/2020/11/Transp_index_2019_ua_full_web-2.pdf

24. Methodology (2013). Methods of rating the openness and systematization of companies in the field of CSR. URL: http://kontrakty.ua/doc/methods_CSR_2013.pdf

25. Lavnikevich, D. (2020). Top 25 best CSR programs. URL: https://www.dsnews.ua/vlast_deneg/top-25luchshih-programm-kso-27072020-393543

26. Vinuesa, R., Azizpour, H., Leite, I. et al. The role of artificial intelligence in achieving the Sustainable Development Goals. Nat Commun 11, 233 (2020). URL: https://www.nature.com/articles/s41467-01914108-y

27. UNIAN. The top 20 companies that implement the best corporate and social practices in Ukraine were noted in Kyiv. URL: https://www.unian.ua/society/10609704-u-kiyevi-vidznachili-top-20-kompaniy-yakivprovadzhuyut-krashchi-korporativno-socialni-praktiki-v-ukrajini.html

Филюк Г.М., д.е.н., профессор, заслужений економіст України

Піменова О.В., к.е.Н., доцент

Піменов С.А., доктор філософрії, МBA

Голованенко М.В., к.е.н., доцент

КНУ имени Тараса Шевченка 


\section{РЕТРОСПЕКТИВНИЙ АНАЛІЗ ВПЛИВУ БІЗНЕС-МОДЕЛЕЙ ПІДПРИЄМСТВ НА НАВКОЛИШНЄ СЕРЕДОВИЩЕ ТА СУСПІЛЬСТВО}

Метою статmі $\epsilon$ дослідження впливу бізнес-моделей сучасних підприємств на навколишнє середовище і суспільство та яким чином цей вплив змінився за останні десятиліття.

Гіпотеза. Ми припускаємо, що чим економічно вигідніша бізнес-модель підприємства, за відсутності контролю та регулювання, тим більшу шкоду завдають підприємства навколишньому середовищу та загострюють соціальні проблеми, особливо в бідних країнах.

Методологія дослідження - В статmі аналізується вплив сучасних бізнесмоделей великих підприємств на соціально-економічне середовище на основі неокласичних підходів економічної теорії, а також теорії класичної школи політичної економії з одного боку та концепції сталого розвитку та концепції екологічної економіки, з іншого боку. Крім того, у процесі дослідження були використані такі методи: монографрічний (аналіз екологічних та соціальних наслідків впровадження існуючих бізнес-моделей підприємств); ретроспективний аналіз (аналіз екологічних та соціальних наслідків у процесі зміни бізнес-моделей підприємств), порівняльний аналіз (виявлені особливості методів оцінки підприємства, які включають використання інтегрованого методу та системного аналізу розкриття інформації, а також КСВ діяльності); емпіричний (щодо оцінки соціальних та екологічних наслідків впровадження бізнес-моделей великих підприємств та концентрації великих масивів сільськогосподарських угідь в руках національних $i$ трансконтинентальних промислових і комерційних компаній); абстрактнологічний (узагальнення та фрормулювання основних висновків і пропозицій за результатами дослідження).

Висновки - 3 метою підвищення об'єктивності та повноти інфрормації щодо специфіки діяльності компаній, зокрема щодо їх впливу на навколишнє середовище, суспільство та інших зацікавлених сторін, ми пропонуємо оцінювати компанії, насамперед, на основі анкет та прямих інтерв'ю $і$, подруге, на основі інформації з відкритих джерел, а також порівнювати їх між собою, що має стати предметом подальших наукових досліджень.

Ключові слова: бізнес-модель підприємства, сталий розвиток, рейтинг підприємств, стейкхолдери, екологічні наслідки, соціальні наслідки. 